\title{
Probiotic-loaded microcapsule system for human in situ folate production: Encapsulation and system validation
}

\author{
Philippe E. Ramos a,*, Luís Abrunhosa a ${ }^{\mathrm{a}}$, Ana Pinheiro ${ }^{\mathrm{a}, \mathrm{b}}$, Miguel A. Cerqueira ${ }^{\mathrm{c}}$, Carla Motta ${ }^{\mathrm{d}}$, \\ Isabel Castanheira ${ }^{\mathrm{d}}$, Maria V. Chandra-Hioe ${ }^{\mathrm{e}}$, Jayashree Arcot ${ }^{\mathrm{e}}$, José A. Teixeira ${ }^{\mathrm{a}}$, António A. Vicente ${ }^{\mathrm{a}}$ \\ ${ }^{a}$ CEB - Centre of Biological Engineering, University of Minho, Campus de Gualtar, 4710-057 Braga, Portugal \\ ${ }^{\mathrm{b}}$ Instituto de Biologia Experimental e Tecnológica, Avenida da República, Quinta-do-Marquês, Estação Agronómica Nacional, Apartado 12, 2781-901 Oeiras, Portugal \\ c International Iberian Nanotechnology Laboratory, Av. Mestre José Veiga s/n, 4715-330 Braga, Portugal \\ d Department of Food Safety and Nutrition, National Institute of Health Dr. Ricardo Jorge, Lisbon, Portugal \\ e Food Science and Technology, School of Chemical Engineering, University of New South Wales, Sydney, NSW 2052, Australia
}

\section{A R T I C L E I N F O}

\section{Article history:}

Received 9 July 2016

Received in revised form 21 October 2016

Accepted 23 October 2016

Available online $\mathrm{xxxx}$

\section{Keywords:}

Probiotic

Immobilization

5-Methyltetrahydrofolate

Mucoadhesive

Folic acid

\begin{abstract}
A B S T R A C T
This study focused on the use of a new system, an alginate|E-poly-L-lysine|alginate|chitosan microcapsule (APACM), able to immobilize a folate-producing probiotic, Lactococcus lactis ssp. cremoris (LLC), which provides a new approach to the utilization of capsules and probiotics for in situ production of vitamins. LLC is able to produce $95.25 \pm 26 \mu \mathrm{g} \cdot \mathrm{L}^{-1}$ of folate, during $10 \mathrm{~h}$, and was encapsulated in the APACM. APACM proved its capacity to protect LLC against the harsh conditions of a simulated digestion maintaining a viable concentration of $6 \log \mathrm{CFU} \cdot \mathrm{mL}^{-1}$ of LLC. A nutrients exchange capacity test, was performed using Lactobacillus plantarum UM7, a high lactic acid producer was used here to avoid false negative results. The production and release of $2 \mathrm{~g} \cdot \mathrm{L}^{-1}$ of lactic acid was achieved through encapsulation of $L$. plantarum, after $20 \mathrm{~h}$. The adhesion of APACM to epithelial cells was also quantified, yielding 38\% and 33\% of capsules adhered to HT-29 cells and Caco-2 cells, respectively.
\end{abstract}

(c) 2016 Elsevier Ltd. All rights reserved.

\section{Introduction}

Malnutrition is a problem that still affects one in three people in the world (International Food Policy Research Institute, 2015). There are different reasons explaining this problem, although the lack of some micronutrients, such as folate, can be associated with malnutrition in pregnant women, children, elderly people and in people consuming a limited diet (World Health Organization, 2012, 2014a, b). A possible reason for the occurrence of this problem in elderly people is the decline of the presence of bifidobacteria in their gastrointestinal system, that are responsible for the production of essential group of B vitamins, such as folate (vitamin B9) (LeBlanc et al., 2013). Folate is a vitamin with extreme importance because it is involved in cells' regulatory processes (Jacob, 2000). Considering its importance in the human diet, it has been introduced in food in its synthetic form, folic acid, in order to accomplish the recommended daily intake of $330 \mu \mathrm{g}$ for adults and $600 \mu \mathrm{g}$ for pregnant women (European Food Safety Authority, 2014). However, fortification with synthetic forms has been studied and some studies mention that there are some disadvantages in the utilization of this form (Bailey \& Ayling, 2009; de Meer et al., 2005; Morris \&

\footnotetext{
* Corresponding author.

E-mail address: phramos@ceb.uminho.pt (P.E. Ramos).
}

Tangney, 2007). Considering this, it is clear that there is a need for fortification by a natural form of folate, so that these problems are avoided and the bioavailability of this vitamin is increased. Some probiotic bacteria, such as Lactococcus lactis ssp. cremoris (LLC), Streptococcus thermophilus, Bifidobacterium lactis, Bifidobacterium breve, Bifidobacterium infantis and Bifidobacterium animalis are capable of producing large amounts of natural folate (Crittenden, Martinez, \& Playne, 2003; Sybesma, Starrenburg, Tijsseling, Hoefnagel, \& Hugenholtz, 2003). These bacteria mainly produce the most common natural form that is 5-methyltetrahydrofolate (5-MeTHF), the form that is naturally assimilated by human cells (Scott, 1999). As mentioned before there are some bacteria capable of producing different folate forms, although other characteristics are important considering the direct utilization of these bacteria in the gut, such as their capacity to produce and excrete the vitamin. There are some bacteria able to produce high amounts of extracellular folate $\left(>40 \mu \mathrm{g} \cdot \mathrm{L}^{-1}\right)$ such as: Lactobacillus amylovorus CRL $887\left(68.3 \mu \mathrm{g} \cdot \mathrm{L}^{-1}\right)$ (Emiliano et al., 2014), Lactobacillus plantarum SM $39\left(397 \mu \mathrm{g} \cdot \mathrm{L}^{-1}\right.$ ) (Hugenschmidt, Schwenninger, Gnehm, \& Lacroix, 2010), Lactobacillus delbrueckii ssp. bulgaricus $863\left(86.2 \mu \mathrm{g} \cdot \mathrm{L}^{-1}\right)$, L. lactis ssp. cremoris SK $110\left(41 \mu \mathrm{g} \cdot \mathrm{L}^{-1}\right)$, and Propionibacterium freudenreichii ssp. shermanii B365 $\left(41 \mu \mathrm{g} \cdot \mathrm{L}^{-1}\right)$. However, this production is influenced by the incubation conditions and is totally dependent of the species and strains (Lin \& Young, 2000). Generally, these probiotics are used in a free 
state and mainly for industrial production of folate, that is conventionally produced by chemical processes (Hugenschmidt, Schwenninger, \& Lacroix, 2011).

Probiotics, that are live microorganisms, which when administered in adequate amounts confer a health benefit to the host (Food and Agriculture Organization of the United Nations/World Health Organization, 2001) and have been used to improve human health but two problems have been identified regarding its utilization, which are: i) the low survival rate through passage in the stomach and ii) the low residence time in the gut (Gardiner et al., 2004; Gueimonde \& Salminen, 2006; Klingberg \& Budde, 2006). Regarding the first problem, several studies have indicated the efficiency of microcapsules on the protection of probiotics against these harsh conditions, where materials such as alginate (Chandramouli, Kailasapathy, Peiris, \& Jones, 2004; Mokarram, Mortazavi, Najafi, \& Shahidi, 2009) and chitosan (De Prisco, Maresca, Ongeng, \& Mauriello, 2015; Graff, Hussain, Chaumeil, \& Charrueau, 2008) can be used. The second problem is related with the relatively low residence time that probiotics have in the human gut. Probiotic colonization and consequent adhesion to the intestinal mucosa, a characteristic that has been better understood in recent times, indicating that a probiotic stays no longer than 5-8 days in the human gastrointestinal system (Rattanaprasert, Roos, Hutkins, \& Walter, 2014; Wolf, Garleb, Ataya, \& Casas, 1995), eventually with a residual activity in the latter stages of this period.

To overcome these two problems on probiotics utilization, encapsulation systems that are able to immobilize these microorganisms can be an interesting solution. These systems are able to protect probiotics, to promote the controlled release of some micronutrients and to adhere to the mucus layer (Brun-Graeppi, Richard, Bessodes, Scherman, \& Merten, 2011; Takeuchi et al., 2005). They can be constituted by hydrophilic polymers that typically have muco-adhesive properties (Gombotz \& Wee, 1998). These hydrophilic polymers have charged functional groups that are able to form hydrogen bonds with mucosal surfaces (Dhawan, Singla, \& Sinha, 2004; Khutoryanskiy, 2011). Some of these materials are alginate, poly-L-lysine and chitosan, and have been used to increase the residence time of some microcapsules by adhesion to the intestinal mucus layer (Gombotz \& Wee, 1998; Ma et al., 2015).

Probiotics encapsulation foresee the total release of these microbes into the gut, in order to achieve a direct contact of it with the epithelium. In the other hand, there are immobilization systems that have been used to encapsulate microorganisms, such as bacteria or yeast, in order to create a microreactor able to host and maintain the microorganism in a continuous active state (Callone, Campostrini, Carturan, Cavazza, \& Guzzon, 2008). With this, a high diffusion rate through the microcapsule is necessary to ensure the adequate exchange rate of consumed nutrients and produced metabolites (Genisheva, Teixeira, \& Oliveira, 2014). Immobilization systems are more frequently used in biomedical applications, more specifically for tissue reconstruction. These systems are usually used in gastrointestinal or intravenous administration (Uludag, De Vos, \& Tresco, 2000). In both cases, an adhesion of the microcapsule to the correct site and continuous release of the encapsulated cells is expected (Zhang, Xie, Koh, \& James Lee, 2009). However, these systems were not explored considering the in situ production of vitamins by probiotics.

In a first work, a microcapsule was developed and characterized to be applied in the present work. This structure is an alginate encapsulation system, smaller than $100 \mu \mathrm{m}$, with a rationally designed coating created through layer-by-layer assembly: an alginate $\mid \varepsilon$-poly-L-lysine| alginate|chitosan microcapsule (APACM) (Ramos et al., 2015). Unlike other works using alginate| poly-L-lysine/alginate (APA) microcapsules, APACM has another coating, such as chitosan, that has two main functions, the protection against the harsh conditions of the stomach and to promote the adhesion to the epithelial cells. Therefore, APACM is a new system with unique characteristics and functions (Ramos, Cerqueira, Vicente, \& Teixeira, 2016), because of that no other system (e.g. APA) was used in this work to compare its performance. This research focused on the use of the developed system for the encapsulation of probiotics with a high capacity of producing extracellular folate. The aim of this work was to test this system in terms of its capacity to: i) host probiotic bacteria; ii) pass through the gastrointestinal system; iii) adhere to the intestinal mucus layer; and iv) exchange nutrients and products (probiotic activation) in the intestine, by changing the porosity of a membrane induced by $\mathrm{pH}$, whilst retaining probiotics. This approach was aiming at: i) increasing the residence time of probiotics in the intestine; ii) avoiding, or at least reducing, possible inflammatory responses from the organism due to direct contact with new bacteria; iii) producing natural folate inside the gut where it will be assimilated by the human organism (i.e., the intestine).

\section{Materials and methods}

\subsection{Materials}

Sodium alginate Protanal 8133, Protanal 8223 and Protanal LFR 5/60 were obtained from FMC BioPolymer (Brussels, Belgium). Calcium chloride $\left(\mathrm{CaCl}_{2}\right)$ was purchased from Panreac (Barcelona, Spain). $\varepsilon$-poly- $L^{-}$ lysine ( $\varepsilon$-PLL, MW. $30 \mathrm{kDa}$ ) was purchased from Handary (Brussels, Belgium). Chitosan (MW. 5-10 kDa) was obtained from Golden-Shell Biochemical Co. Ltd. (Yuhuan, China) with a degree of deacetylation of 95\%. Corn oil, Tween 80, rhodamine B isothiocynate (RITC), 1-ethyl-3-(-3dimethylaminopropyl) carbodiimide hydrochloride (EDC), N,Ndimethylformamide and folic acid were purchased from Sigma (St. Louis, USA). M17 and de Man, Rogosa and Sharpe (MRS) were purchased from Oxoid (Hampshire, England). M17 and MRS agar and glucose were purchased from Merck (Munich, Germany). potassium chloride $(\mathrm{KCl})$, monopotassium phosphate $\left(\mathrm{KH}_{2} \mathrm{PO}_{4}\right)$, sodium bicarbonate $\left(\mathrm{NaHCO}_{3}\right)$, sodium chloride $(\mathrm{NaCl})$, magnesium chloride hexahydrate $\left(\mathrm{MgCl}_{2}\left(\mathrm{H}_{2} \mathrm{O}\right)_{6}\right)$, ammonium carbonate $\left(\left(\mathrm{NH}_{4}\right)_{2} \mathrm{CO}_{3}\right)$, calcium chloride dihydrate $\left(\mathrm{CaCl}_{2}\left(\mathrm{H}_{2} \mathrm{O}\right)_{2}\right)$, sulfuric acid $\left(\mathrm{H}_{2} \mathrm{SO}_{4}\right)$, L-Lactic acid $\left(\mathrm{C}_{3} \mathrm{H}_{6} \mathrm{O}_{3}\right)$, hydrogen chloride $(\mathrm{HCl})$, sodium citrate $\left(\mathrm{Na}_{3} \mathrm{C}_{6} \mathrm{H}_{5} \mathrm{O}_{7}\right)$, phosphate-buffered saline (PBS), formic acid, acetonitrile and sodium hydroxide $(\mathrm{NaOH})$ were purchased from Sigma-Aldrich (St. Louis, USA). To perform the gastrointestinal simulation pepsin (from porcine, car no. SLBL2143V, $3616 \mathrm{U} \cdot \mathrm{mg}^{-1}$ ), pancreatin (from porcine, cat no. SLBL3953V, $6.1 \mathrm{U} \cdot \mathrm{mg}^{-1}$ ) and bile salts (from porcine, cat $\mathrm{n}^{\circ}$ SLBK9078V, $164 \mathrm{mM}$ ) were purchased from Sigma-Aldrich. Internal standard of ${ }^{13} \mathrm{C}$ folic acid and ${ }^{13} \mathrm{C}$ of 5 -methyltetrahydrofolate $(5-$ MeTHF), as the standards of the same forms, were purchased from Schircks (Switzerland), as the other folate forms such as tetrahydrofolate (THF), 5-formyltetrahydrofolate (5-FoTHF), 10-methyltetrahydrofolate (10-MeTHF) and 10-formyltetrahydrofolate (10-FoTHF). To perform the adhesion tests with cell culture the following materials were used: fetal Bovine Serum (FBS), penicillin, Dulbecco's Modified Eagle Medium (DMEM), glutamax, Dulbecco's phosphate buffered saline (DPBS) and hank's balanced salt solution (HBSS), all from Invitrogen (Sydney, Australia). Fluorodish dishes (35 mm) were purchased from World Precision Instruments (Sydney, Australia). Caco-2 and HT-29 cells (sourced from American Type Culture Collection, Manassas, USA) were a gift from the Lowy Cancer Research Centre (University of New South Wales, Sydney, Australia). The probiotics used in this work were Lactococcus lactis ssp. cremoris SK 110 obtained from Nizo (Nizo Food Research, Ede, The Netherlands) and L. plantarum UM7 isolated from cow milk and obtained from our private collection of lactic acid bacteria.

\subsection{Bacterial growth and preparation of cell suspensions}

Probiotic bacteria Lactococcus lactis ssp. cremoris (Nizo Food Research, Ede, The Netherlands). Probiotic LLC was cultured and propagated, overnight, in $200 \mathrm{~mL}$ of M17 broth at $30{ }^{\circ} \mathrm{C}$ (Certomat $\mathrm{H}, \mathrm{GCC}$, Singapore), in a $500 \mathrm{~mL}$ flask with a stopper, under anaerobic conditions. The cells of bacteria were collected by centrifugation at $2000 \mathrm{~g}$ 
for 5 min (Heraeus Megafuge 1.0R, Buckinghamshire, England), and washed twice in PBS ( $\mathrm{pH}$ 7.4). Bacteria was then suspended in PBS solution to be used in each experiment. The same protocol was used for $L$. plantarum UM7 although MRS broth was used, instead of M17 broth. To perform the tests in aseptic conditions the polymeric solutions were filtered through a $0.2 \mu \mathrm{m}$ filter (Acro, Pall, San Diego, USA) and the other solutions and material used were sterilized.

\subsection{Microcapsules production and probiotic microencapsulation}

Microcapsules were produced according to the method described by Sheu and Marshall (1993). These first tests were performed without bacteria to facilitate the characterization of the coated microcapsule, although for the subsequent tests LLC was mixed with the alginate solution. The microcapsules were produced by dropwise addition of $20 \mathrm{~mL}$ of a sodium alginate solution, with a concentration of $1.5 \%$, into a $100 \mathrm{~mL}$ solution of vegetable oil with a concentration of $0.2 \%$ of Tween 80. The mixture was then stirred for $10 \mathrm{~min}$ at $200 \mathrm{rpm}$. After this, a solution of $200 \mathrm{~mL}$ of $\mathrm{CaCl}_{2}\left(0.05 \mathrm{~mol} \cdot \mathrm{L}^{-1}\right)$ was gently added over $20 \mathrm{~s}$ and the mixture stirred at $200 \mathrm{rpm}$ for $20 \mathrm{~min}$. After hardening, the solution was passed through a decanting funnel, where it remained for $30 \mathrm{~min}$. After this, the liquid (oil and water) was gently removed with a pipette. The residual volume containing the microcapsules was then filtered through a $100 \mu \mathrm{m}$ nylon filter (GVW, Millipore, Jaffrey, USA) using water to remove the residual oil. After filtration, the microcapsules that passed through the filter (smaller than $100 \mu \mathrm{m}$ - because capsules smaller than $100 \mu \mathrm{m}$ do not create a gritty sensation when added into food) were centrifuged for $5 \mathrm{~min}$ at $600 \mathrm{rpm}$ (Heraeus Megafuge 1.0R, Buckinghamshire, England) and the supernatant was removed.

\subsection{Layer-by-layer assembly}

After production,the microcapsules were immersed in a $0.01 \% \varepsilon$-PLL solution $(10 \mathrm{~mL})$, with constant stirring at $200 \mathrm{rpm}$ during $15 \mathrm{~min}$, creating the coated microcapsules with a single coat. After that, the solution was again centrifuged in the same conditions as described in Section 2.3. The next step was the immersion of the coated microcapsules into a sodium alginate solution $(0.1 \%, 10 \mathrm{~mL})$ for $15 \mathrm{~min}$, followed by centrifugation ( $600 \mathrm{rpm}, 10 \mathrm{~min}$ ). The recovered coated microcapsules (now double coated) were then immersed into a chitosan solution $(0.01 \%, 10 \mathrm{~mL})$. After that, another centrifugation step separated the now triple coated microcapsules (APACM) from the chitosan solution.

\subsection{Chitosan labelling with rhodamine $B$}

Chitosan-[RITC] was prepared by mixing $100 \mathrm{~mL}$ of $1 \%$ chitosan with $50 \mathrm{mg}$ RITC and $20 \mathrm{mg}$ EDC at $4{ }^{\circ} \mathrm{C}$ for 1 day. The residual free dye was then dialyzed off (molecular weight cut-off 3500 Da; Cell-Sep. H1, Spectrum, Rancho Dominguez, USA) with double distilled water for four weeks (Chang, Lee, Wu, Yang, \& Chien, 2012). The solution was stirred overnight and isolated by freeze-drying (Kleinberger, Burke, DalnokiVeress, \& Stöver, 2013).

\subsection{Confocal microscopy analyses during harmonized in vitro gastrointes- tinal simulation}

For the study of chitosan adhesion during the gastrointestinal simulation tests, confocal images were taken in the beginning and at the end of the gastric and intestinal digestion steps of the harmonized in vitro digestion protocol. All samples were analyzed by confocal microscopy (Olympus BX61, Model FluoView 1000, Munich, Germany).

\subsection{Harmonized in vitro gastrointestinal simulation}

For the gastrointestinal simulation the protocol presented by Minekus et al. (2014a) was used with some modifications. The solutions used were Simulated Salivary Fluid (SSF) - $\mathrm{KCl} 15.1 \mathrm{mM} \cdot \mathrm{L}^{-1}, \mathrm{KH}_{2} \mathrm{PO}_{4}$ $3.7 \mathrm{mM} \cdot \mathrm{L}^{-1}, \mathrm{NaHCO}_{3} 13.6 \mathrm{mM} \cdot \mathrm{L}^{-1}, \mathrm{MgCl}_{2}\left(\mathrm{H}_{2} \mathrm{O}\right)_{6} 0.15 \mathrm{mM} \cdot \mathrm{L}^{-1}$, $\left(\mathrm{NH}_{4}\right)_{2} \mathrm{CO}_{3} \quad 0.06 \mathrm{mM} \cdot \mathrm{L}^{-1}, \mathrm{CaCl}_{2}\left(\mathrm{H}_{2} \mathrm{O}\right)_{2} \quad 1.5 \mathrm{mM} \cdot \mathrm{L}^{-1}$ and $\mathrm{HCl}$ $1.1 \mathrm{mM} \cdot \mathrm{L}^{-1}$, Simulated Gastric Fluid (SGF) - KCl $6.9 \mathrm{mM} \cdot \mathrm{L}^{-1}, \mathrm{KH}_{2} \mathrm{PO}_{4}$ $0.9 \mathrm{mM} \cdot \mathrm{L}^{-1}, \mathrm{NaHCO}_{3} 25 \mathrm{mM} \cdot \mathrm{L}^{-1}, \mathrm{NaCl} 47.9 \mathrm{mM} \cdot \mathrm{L}^{-1}, \mathrm{MgCl}_{2}\left(\mathrm{H}_{2} \mathrm{O}\right)_{6}$ $0.12 \mathrm{mM} \cdot \mathrm{L}^{-1},\left(\mathrm{NH}_{4}\right)_{2} \mathrm{CO}_{3} 0.5 \mathrm{mM} \cdot \mathrm{L}^{-1}, \mathrm{CaCl}_{2}\left(\mathrm{H}_{2} \mathrm{O}\right)_{2} 0.15 \mathrm{mM} \cdot \mathrm{L}^{-1}$ and $\mathrm{HCl} 15.6 \mathrm{mM} \cdot \mathrm{L}^{-1}$ and Simulated Intestinal Fluid (SIF) $-\mathrm{KCl}$ $6.8 \mathrm{mM} \cdot \mathrm{L}^{-1}, \mathrm{KH}_{2} \mathrm{PO}_{4} 0.8 \mathrm{mM} \cdot \mathrm{L}^{-1}, \mathrm{NaHCO}_{3} 85 \mathrm{mM} \cdot \mathrm{L}^{-1}, \mathrm{NaCl}$ $38.4 \mathrm{mM} \cdot \mathrm{L}^{-1}, \mathrm{MgCl}_{2}\left(\mathrm{H}_{2} \mathrm{O}\right)_{6} 0.33 \mathrm{mM} \cdot \mathrm{L}^{-1}, \mathrm{CaCl}_{2}\left(\mathrm{H}_{2} \mathrm{O}\right)_{2} 0.6 \mathrm{mM} \cdot \mathrm{L}^{-1}$ and $\mathrm{HCl} 8.4 \mathrm{mM} \cdot \mathrm{L}^{-1}$. These solutions were warmed-up at $37{ }^{\circ} \mathrm{C}$ before the experiment started.

The protocol started with the addition of $5 \mathrm{~g}$ of sample (PBS solution with the microcapsules, with or without LLC) in a $50 \mathrm{~mL}$ Falcon tube with $4 \mathrm{~mL}$ of SSF. This mixture was incubated for $2 \mathrm{~min}$ at $37^{\circ} \mathrm{C}$ (all the incubation steps were performed at this temperature and shaking conditions). In the next step $8 \mathrm{~mL}$ of SGF was added into a calculated volume of porcine pepsin in water (an exact volume to achieve a $2000 \mathrm{U} \cdot \mathrm{mL}^{-1}$ in the final mixture) and adjusted to $\mathrm{pH} 2$ (using an $\mathrm{HCl}$ $1 \mathrm{M}$ solution). The mixture was incubated for $2 \mathrm{~h}$. After this, a pancreatin suspension (an exact volume to achieve a $200 \mathrm{U} \cdot \mathrm{mL}^{-1}$ in the final mixture), a certain volume of bile solution (an exact volume to achieve a final concentration of $10 \mathrm{mmol} \cdot \mathrm{L}^{-1}$ ) and $8 \mathrm{~mL}$ of SIF were added. The samples were incubated for $2 \mathrm{~h}$. Samples were removed every $30 \mathrm{~min}$ during the gastric and intestinal simulations. All the samples were tested at least in triplicate and in order to perform more practical $\mathrm{pH}$ adjustments, one replicate test tube with $5 \mathrm{~mL}$ of each sample was preprepared and the $\mathrm{NaOH}$ and $\mathrm{HCl}$ volumes used were kept along the digestion protocol as initial reference.

2.8. Viability study of the encapsulated LLC on the APACM during the gastrointestinal simulation tests

To study the viability of microencapsulated LLC, samples were taken every 30 min during the stomach and intestinal simulations. After that each sample was mixed with a $10 \mathrm{~mL}$ sodium citrate solution $(0.1 \%$, $\mathrm{w} / \mathrm{v}$ ) and stirred for $30 \mathrm{~min}$ for total destruction of the coated microcapsules, after which a sample of $1 \mathrm{~mL}$ was retrieved and serially diluted before being plated onto a M17 agar.

\subsection{Folate production by LLC}

Bacterial folate production tests were performed in $250 \mathrm{~mL}$ vessels, with $200 \mathrm{~mL}$ of M17 medium. The bacteria were introduced in order to achieve an initial concentration of at least $8 \log \mathrm{CFU} \cdot \mathrm{mL}^{-1}$. The experiments were performed at $30{ }^{\circ} \mathrm{C}$ under anaerobic conditions. Samples were taken at 5, 10, 23 and $48 \mathrm{~h}, 5 \mathrm{~mL}$, and were centrifuged at $6000 \mathrm{rpm}$, during $10 \mathrm{~min}$, and washed/re-suspended with PBS. The quantification of LLC was performed by measuring the optical density at $600 \mathrm{~nm}$ (ELISA, Bio-tek, Winooski, USA) using a calibration curve (number of bacterial cells $v s$ optical density). The experiments were performed in triplicate.

\subsection{Folate quantification by UPLC}

All folate produced by LLC test samples, $1 \mathrm{~mL}$ of each, were suspended into $10 \mathrm{~mL}$ of a bicarbonate buffer $0.5 \mathrm{mmol} \cdot \mathrm{L}^{-1}$ with $0.5 \%$ of dieritrotietol (DTT) and 1\% of ascorbic acid, at pH 7.2 (with internal standard of $100 \mathrm{ng} \cdot \mathrm{mL}^{-1}$ of ${ }^{13} \mathrm{C}$ folic acid and ${ }^{13} \mathrm{C} 5$-MeTHF). After that, all samples were submitted to boiling for $10 \mathrm{~min}$ and cooled down in ice at the end. After that the samples were centrifuged in an Amicon filter ( $5 \mathrm{kDa}$ ), at $13,000 \mathrm{~g}$, during $50 \mathrm{~min}$ at $4{ }^{\circ} \mathrm{C}$.

To quantify the amount of folate produced, different standards were used, such as folic acid, THF, 5-MeTHF, 5-FoTHF, 10-MeTHF and 10FoTHF. To perform this experiment an Ultra performance liquid chromatography - tandem mass spectrometer (UPLC - MS/MS, Thermo Fisher, Waltham, USA), an AcQuity UPLC-TQD with an AcQuity HSS T3 
$1.8 \mu \mathrm{m} 2.1 \times 150 \mathrm{~mm}$ column at $45^{\circ} \mathrm{C}$ was used (Waters, Milford, USA). The gradient mobile phase was $0.1 \%$ of formic acid (A) and $99 \%$ of acetonitrile (B) at $0.4 \mathrm{~mL} \cdot \mathrm{min}^{-1}$ (Motta, 2015).

\subsection{Assessment of lactic acid production by the system}

The low production of folate, by LLC, or even lactic acid, required the utilization of a probiotic able to produce in amounts high enough to quantify. Because of that L. plantarum UM7 was used considering its probiotic characteristics and its high capacity to produce lactic acid in high amounts. Fermentation was performed using L. plantarum UM7 encapsulated by emulsification, with the APACM system. The APACM were filtered in a sterile Millipore filter, with a $10 \mu \mathrm{m}$ cut-off. After that, the APACM was introduced into MRS broth $(200 \mathrm{~mL})$ and incubated at $30{ }^{\circ} \mathrm{C}$, without aeration and at an agitation rate of $130 \mathrm{rpm}$. The same amount of $L$. plantarum UM7 which was encapsulated before, was introduced as free bacteria into another flask with MRS broth $(200 \mathrm{~mL})$. These tests were performed in triplicate during $44 \mathrm{~h}$; samples were collected at 0, 4, 20, 27 and $44 \mathrm{~h}$. The sampling was performed in two steps: in the first step each sample was filtered with a $10 \mu \mathrm{m}$ cut-off filter (to retain the APACM) and this filter was suspended into a sodium citrate solution $(0.1 \%, \mathrm{w} / \mathrm{v})$ for bacterial viability quantification (Section 2.8$)$; in step two the filtered sample was centrifuged, where the pellet was used for bacteria viability quantification (Section 2.8) and the liquid was analyzed on a high performance liquid chromatography (HPLC) to quantify lactic acid and glucose. With the experiment using free $L$. plantarum UM7, just step two was performed.

\subsection{HPLC quantification of glucose and lactic acid}

The quantification of glucose and lactic acid was performed by HPLC using a system that comprised of a Jasco 880-PU pump, a Jasco AS2057 Plus autosampler, a RI Jasco RI-1530 detector and a SFD 05-015 oven (Easton, USA). The chromatographic separation, was performed with a $20 \mathrm{~min}$ isocratic run on a MetaCarb $67 \mathrm{H}$ column $(300 \times 7.8 \mathrm{~mm}$, Agilent technologies, Santa Clara, USA). Eluent was $0.005 \mathrm{~mol} \cdot \mathrm{L}^{-1} \mathrm{H}_{2} \mathrm{SO}_{4}$ filtered and degassed with a $0.2 \mu \mathrm{m}$ membrane filter (GHP, Gelman, Pall, New York, USA). The flow rate was set to $0.7 \mathrm{~mL} \cdot \mathrm{min}^{-1}$ and the column temperature to $60^{\circ} \mathrm{C}$. The injection volume was $20 \mu \mathrm{L}$. L-Glucose and Llactic acid were identified by retention time ( 9 and $17 \mathrm{~min}$, respectively) and quantified by comparing peak areas with respective calibration curves ( -glucose - $\mathrm{y}=11.634 \mathrm{x}-0.2288\left(R^{2}=0.999\right)$; L-lactic acid $\left.-\mathrm{y}=5038.8 \mathrm{x}-261.45\left(R^{2}=0.999\right)\right)$.

\subsection{Adhesion experiments}

HT-29 cells were routinely grown in McCoy's growth medium (with $10 \%(\mathrm{v} / \mathrm{v})$ of FBS and $1 \%(\mathrm{v} / \mathrm{v})$ of penicillin). Caco-2 cells were routinely grown in DMEM (with $10 \%(\mathrm{v} / \mathrm{v})$ of FBS, $1 \%(\mathrm{v} / \mathrm{v})$ of glutamax and $1 \%(\mathrm{v} /$ $\mathrm{v}$ ) of penicillin). Both were incubated in a humidified $5 \% \mathrm{CO}_{2}$ atmosphere, at $37{ }^{\circ} \mathrm{C}$ for 15 and 21 days (Model 5.3A, VWR, Radnor, USA). These conditions are according to the ATCC protocol. The tests were performed by the utilization of Fluorodishes where a density of $5.5 \times 10$ ${ }^{4}$ cells $\cdot \mathrm{cm}^{-2}$ was used and left to grow until differentiation (1520 days), as was done in other studies (Chen, Cao, Ferguson, Shu, \& Garg, 2012; Garcia-Fuentes, Prego, Torres, \& Alonso, 2005). To perform in vitro tests the growth medium of the dishes was gently removed and $2 \mathrm{~mL}$ of APACM (where the chitosan coating was labelled with rhodamine B), was suspended in HBSS with a concentration of $2 \mathrm{mg} \cdot \mathrm{mL}^{-1}$, and placed on the top of the cells. The dishes were incubated in a humidified $5 \% \mathrm{CO}_{2}$ atmosphere, at $37^{\circ} \mathrm{C}$ during $1 \mathrm{~h}$. After $1 \mathrm{~h}$ the HBSS medium was removed and the cells were washed twice with DPBS. After that, the dishes were analyzed by confocal microscopy (Olympus FV1200, Tokyo, Japan) where 10 pictures were taken of different areas in each dish to count the adhered APACM. With these results and knowing the number of APACM placed in each dish at the beginning of the experiment, it was possible to quantify the amount of APACM at the end of each test.

\subsection{Statistical analyses}

Statistical analyses were performed using the analyses of variance (ANOVA) procedure with SigmaPlot 11.0 software for Windows (SigmaPlot 11.0, Systat, San Jose, USA), where a $p<0.05$ was considered to be statistically significant.

\section{Results and discussion}

\subsection{The stability of APACM during in vitro gastrointestinal simulation}

Gastrointestinal conditions are harsh for probiotics and bacteria in general, as mentioned before. Because of that, it was important to understand how the coatings, once applied to the microcapsule, will behave after their passage through the stomach and intestine, allowing to evaluate the performance of this encapsulation system. Fig. 1 shows APACM after the gastrointestinal digestion simulation where the chitosan coating is presented in red, due to its labelling with rhodamine B. Results proved that even after the gastrointestinal digestion simulation the APACM was stable with the last coating still attached. As mentioned before, the stability of these materials used as coatings in gastrointestinal simulations tests was also proven by other authors (Cui, Goh, Kim, Choi, \& Lee, 2000; Kamalian, Mirhosseini, Mustafa, \& Manap, 2014; Krasaekoopt, Bhandari, \& Deeth, 2006a; Tam et al., 2011), although it was never performed with three coatings and with this specific combination of materials.

\subsection{Viability of microencapsulated LLC in a gastrointestinal simulation}

The results of the viability of free and encapsulated LLC are presented in Fig. 2. The experiment of free LLC showed an instantaneous death of most of the LLC already in the first moments of the gastric phase of the digestive process. The same results were also achieved by other authors where an immediate death of most, or even all free bacteria happens during the stomach simulation test, that is a consequence of the low pH of the medium (Cook, Tzortzis, Charalampopoulos, \& Khutoryanskiy, 2011; García-Ceja, Mani-López, Palou, \& López-Malo, 2015; Gbassi, Vandamme, Ennahar, \& Marchioni, 2009; Iyer, Phillips, \& Kailasapathy, 2005; Krasaekoopt, Bhandari, \& Deeth, 2004; Lee, Cha, \& Park, 2004; Sohail, Turner, Coombes, Bostrom, \& Bhandari, 2011). Chitosan coating has a considerable positive effect on the protection of

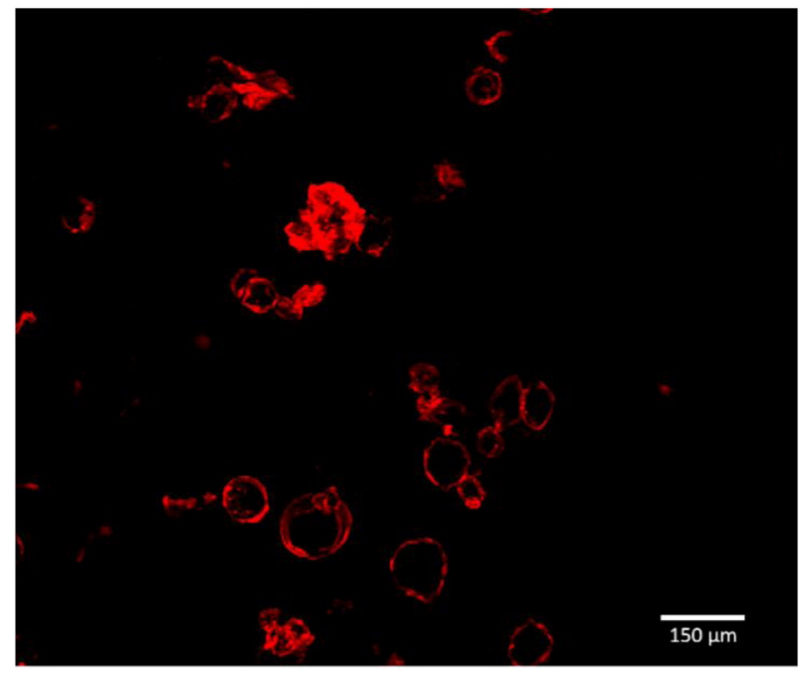

Fig. 1. APACM with chitosan as the last coating (chitosan labelled with rhodamine) after the in vitro gastrointestinal simulation. 


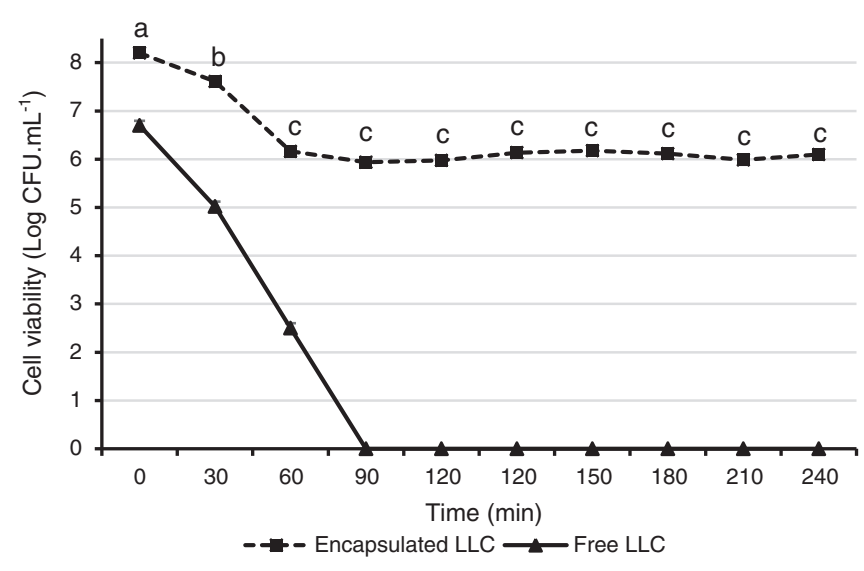

Fig. 2. Cell viability during the gastrointestinal digestion simulation - the first $120 \mathrm{~min}$ corresponds to the simulation of the stomach digestion and the subsequent $120 \mathrm{~min}$ (until $240 \mathrm{~min}$ ) corresponds to the simulation of intestinal digestion.

encapsulated probiotics, but a high number of coatings and combinations of materials tested did not bring significant advantages for probiotics protection (Cook et al., 2011; García-Ceja et al., 2015; Iyer \& Kailasapathy, 2005; Krasaekoopt et al., 2004; Lee et al., 2004; Mi, Su, Fan, Zhu, \& Zhang, 2013; Sohail et al., 2011). The presence of three coatings on APACM has different purposes, as mentioned in a previous work focused on the design of this system (Ramos et al., 2015), having all the materials to prove their capacity for probiotic protection in gastrointestinal simulation tests (Annan, Borza, \& Hansen, 2008; Iyer \& Kailasapathy, 2005; Krasaekoopt et al., 2004; Mokarram et al., 2009a). After the first hour the viability of free LLC decreased to <$4 \log \mathrm{CFU} \cdot \mathrm{mL}^{-1}$, whilst no viable free LLC were present after $90 \mathrm{~min}$. The viability of encapsulated LLC also decreased during the first hour, although it remained stable until the end of the experiment at a value of $6 \log \mathrm{CFU} \cdot \mathrm{mL}^{-1}$. These results show that the APACM is capable of protecting LLC during the gastrointestinal digestion simulation.

\subsection{Folate production by free $L L C$}

As mentioned in other studies, natural folate production by bacteria implies the utilization of a high concentration of microorganisms with optimal conditions for folate production. For this, a minimal concentration of $8 \log \mathrm{CFU} \cdot \mathrm{mL}^{-1}$ was used at $30{ }^{\circ} \mathrm{C}$ under anaerobic conditions (Fig. 3).

LLC is an important industrial microorganism for cheese production and has a GRAS status (Jeong et al., 2006; Kilstrup \& Hammer, 2000). As

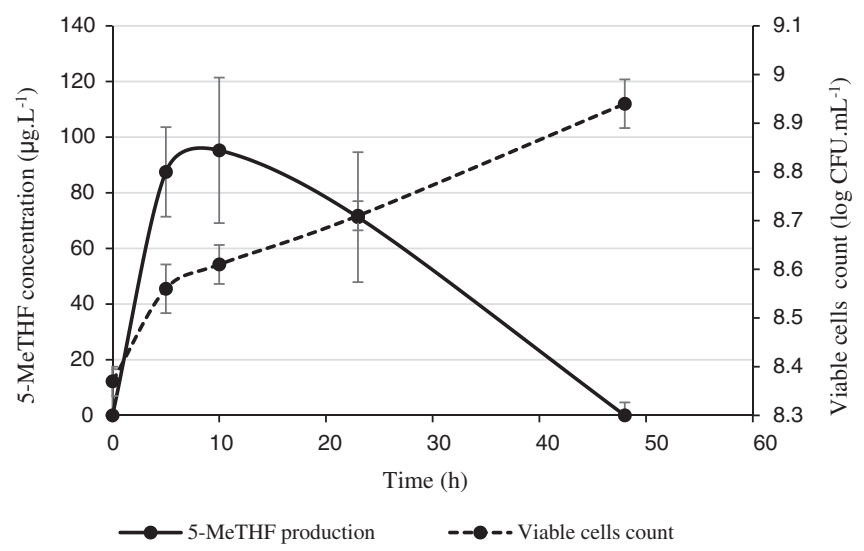

Fig. 3. Continuous production of folate by LLC during $48 \mathrm{~h}$; the black line represents the produced folate, specifically 5-MeTHF, and the black broken line represents LLC concentration. mentioned before this microorganism has the capacity of producing folate and excreting it, which are important functions considering the purpose of APACM. Fig. 3 shows the production of folate by LLC during $48 \mathrm{~h}$ in M17 broth. According to these results just 5-MeTHF was present in all samples, being the only folate form produced by LLC. Results are in agreement with literature sources where this folate form is commonly associated with microbial strains producing this vitamin (Lin \& Young, 2000; Scott, 1999). Considering the form of folate produced by LLC, it was also interesting to observe that the highest amount achieved by cumulative quantification attained at $10 \mathrm{~h}$ was $95.25 \pm 26 \mu \mathrm{g} \cdot \mathrm{L}^{-1}$. These data are in accordance with tests performed with other bacteria able to produce folate, where the maximum folate production was achieved after $6-10 \mathrm{~h}$, after which a decrease happens due to its consumption by the bacteria (Holasová, Fiedlerová, Roubal, \& Pechacová, 2002; Laiño, Leblanc, \& Savoy de Giori, 2012; Lin \& Young, 2000).

\subsection{Validation of the exchange of nutrients in APACMs}

This test was performed to validate APACM as a system capable of activating the immobilized probiotics by allowing the entrance of essential nutrients, and releasing nutrients produced by the immobilized probiotics. These two events are referred to as the APACM's nutrients exchange capacity.

In order to show the APACM's nutrients exchange capacity it would be interesting to encapsulate LLC bacteria, introduce these capsules into M17 broth and quantify the folate that would be produced and released to the medium. However, the amount of folate produced by LLC, as demonstrated before, was $95.25 \pm 26 \mu \mathrm{g} \cdot \mathrm{L}^{-1}$ with an initial LLC concentration of $8 \log \mathrm{CFU} \cdot \mathrm{mL}^{-1}$ which was easily achieved when this test was performed with free bacteria. When the test needs to be performed with encapsulated bacteria an inherent limitation is the encapsulation efficiency of the capsules' production technique. In fact, the encapsulation efficiency (EE) is only $30 \pm 2 \%$ LLC and after the filtration process, that allows keeping only the capsules smaller than $100 \mu \mathrm{m}$, an LLC EE of $1 \pm 0.5 \%$. This led to an initial encapsulated LLC concentration of $<-$ $7 \log \mathrm{CFU} \cdot \mathrm{mL}^{-1}$, which was not sufficient to allow quantification of any form of folate (this was tried using UPLC, but without success - results not shown).

After these results, it was clear that other probiotic bacteria that were able to produce enough folate to be able to be quantified were needed. L. plantarum UM7, also a probiotic, was used once as it is able to produce high amounts of lactic acid (Belicová, Mikulášová, \& Dušinský, 2013; Ramos, Thorsen, Schwan, \& Jespersen, 2013), although this L. plantarum UM7 does not have the capacity to produce vitamins. Therefore, L. plantarum UM7 was just used in this work to prove the nutrients exchange capacity of the system, being the other tests presented before developed with LLC, a folate producer.

Therefore L. plantarum UM7 was encapsulated in APACM and a nutrients exchange capacity validation was performed by the quantification of glucose and lactic acid, the carbon source and the fermentation product, respectively. These tests were performed in MRS broth, and the results were compared with those of a test with free L. plantarum. All samples were analyzed using the HPLC and the results are presented in Figs. 4 and 5.

According to the results presented in Fig. 4 it is possible to conclude that $L$. plantarum UM7 is capable of a high production of lactic acid, achieving a total consumption of glucose in approximately $30 \mathrm{~h}$. At that stage, a cell concentration of $9 \log \mathrm{CFU} \cdot \mathrm{mL}^{-1}$ was achieved and the bacteria were totally dedicated to the fermentation process, producing $5 \mathrm{~g} \cdot \mathrm{L}^{-1}$ of lactic acid in $7 \mathrm{~h}$ (between $20 \mathrm{~h}$ sample and $27 \mathrm{~h}$ sample). The maximum production rate of free L. plantarum UM7 was achieved between 4 and $20 \mathrm{~h}$, being the production rate of lactic acid per bacteria $\left(Y_{P / B}\right)$ of $8.71 \times 10^{-9} \mathrm{mg} \cdot$ bacteria $^{-1}$, during that period of time.

Comparing Fig. 4 with Fig. 5 it is possible to see that the consumption of glucose and consequent production of lactic acid was slower in the encapsulated L. plantarum UM7 experiment (Fig. 5) than with the free 


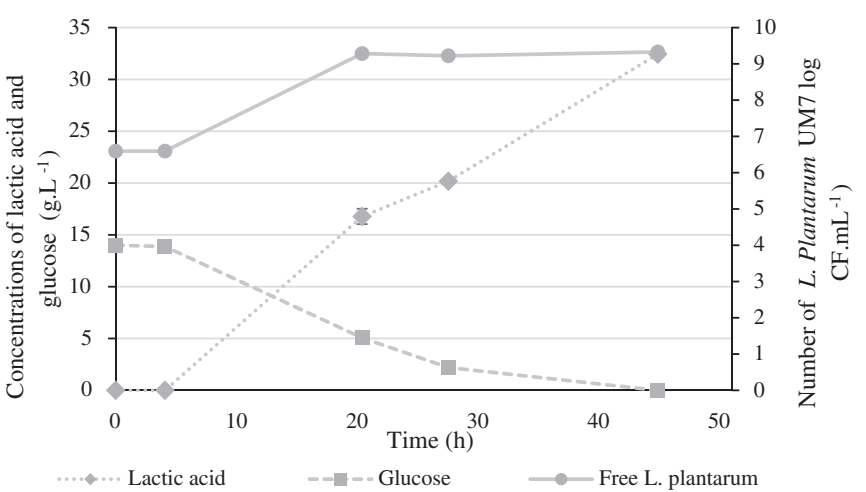

Fig. 4. Free L. plantarum UM7 production of lactic acid and consumption of glucose at $30^{\circ} \mathrm{C}$, in MRS broth.

L. plantarum UM7 experiment (Fig. 4). Fig. 5 shows that a total consumption of glucose was achieved and that the same amount of lactic acid was produced as reported in Fig. 4 (app. $30 \mathrm{~g} \cdot \mathrm{L}^{-1}$ ). During the tests reported in Fig. 5 it is important to mention that, even if all the $L$. plantarum UM7 were encapsulated in the beginning of the experiment, during the $30 \mathrm{~h}$ of test some bacteria were released. The amount of free L. plantarum, mainly after the $27 \mathrm{~h}$ of the test, prevents us from drawing conclusions regarding the performance of encapsulated bacteria during that period. Nevertheless, conclusions can be made from the first $20 \mathrm{~h}$ of the experiment, during which approximately $2 \mathrm{~g} \cdot \mathrm{L}^{-1}$ of lactic acid were produced; at that point the amount of free L. plantarum UM7 was just $3 \log \mathrm{CFU} \cdot \mathrm{mL}^{-1}$ and the amount of encapsulated L. plantarum UM7 was of $8 \log \mathrm{CFU} \cdot \mathrm{mL}^{-1}$. Using data from Fig. 4, specifically the value of $Y_{P / B}$ of the free L. plantarum, it is possible to conclude that the existing concentration of free bacteria $\left(3 \log \mathrm{CFU} \cdot \mathrm{mL}^{-1}\right)$ in the encapsulated $L$. plantarum UM7 experiment could only produce $7.3 \times 10^{-9} \mathrm{~g} \cdot \mathrm{L}^{-1}$ of lactic acid. This means that the $2 \mathrm{~g} \cdot \mathrm{L}^{-1}$ of lactic acid obtained in this experiment were mostly produced by the encapsulated L. plantarum.

These results let us conclude that the exchange of nutrients on the APACM actually occurs, which allows validating the system's behaviour considering its main goals of hosting a probiotic bacterium, activating it and allowing the release of the products.

Another conclusion is that even with a partial release of L. plantarum UM7 during the test, an important concentration of cells was kept encapsulated and maintained its viability throughout the experiment. This fact allows concluding that the APACM was also able to immobilize the encapsulated L. plantarum UM7 at $30 \mathrm{~h}$.

\subsection{Adhesion experiments}

This last section evaluates the capacity of APACM to adhere to live cells, mimicking the adhesion in an intestinal environment.

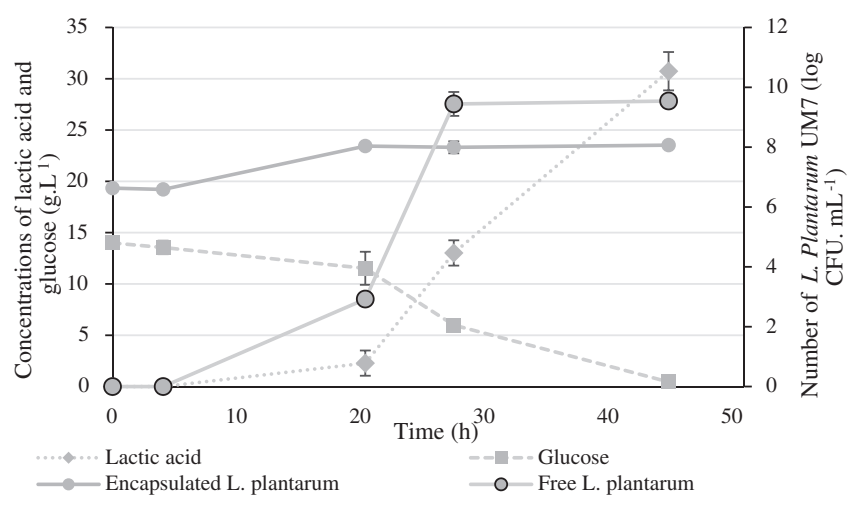

Fig. 5. APACM exchange of nutrients validation through the production of lactic acid by $L$. plantarum $\mathrm{UM} 7$, at $30^{\circ} \mathrm{C}$, in MRS broth.
As discussed before, elderly people have significant problems regarding the loss of essential microflora that might lead to malnutrition. A possible justification for that problem is the loss of mucus on the intestinal epithelium surface during ageing (Patel, Singh, Panaich, \& Cardozo, 2014; Tiihonen, Ouwehand, \& Rautonen, 2010). Caco-2 and HT-29 cells were used as models to predict how the intestine of an elderly person, with loss of mucus, would react regarding the adhesion of a capsule. Caco-2 cells are not producers of mucus whilst HT-29 cells are partial producers of mucus, therefore being interesting models of the intestinal epithelium (Huet et al., 1995). An important function of APACM would thus be their capacity to adhere to the epithelium, or more specifically to a mucus-deficient epithelium. Testing such capacity would provide information about how this system could serve as a solution for the increase of folate production in situ. To accomplish that, the APACM design was planned using only mucoadhesive materials, such as alginate, $\varepsilon$-PLL and chitosan (Chen et al., 2012; George \& Abraham, 2006; Ghersd, Jolliffe, Hampson, \& Dettmar, 1998; Gombotz \& Wee, 1998; Luo \& Wang, 2014; Ma et al., 2015; Matsumura, Nakajima, Sugai, \& Hyon, 2014; Sarmento et al., 2007; Sinha et al., 2004). The main idea was that, even if the APACM lost some of its coating, the other coatings would be able to adhere properly to the epithelium structure. APACM were tested on Caco-2 and HT-29 cells, with 15 and 21 days of differentiation, thus testing four independent conditions as shown in Fig. 6. The results show that there were no significant differences between the results obtained with cells having 15 and 21 days of differentiation $(p<0.05)$. The study of APACM adhesion to the cells showed that the coated capsules are capable of adhering to epithelial cells, with an adhesion to 38\% HT-29 cells and to 33\% of Caco-2 cells (Fig. 7). This difference might be due to the production of mucin by the HT-29 cells, which may have increased the adhesion to these cells.

These results are in agreement with those of chitosan-coated capsules where a percentage of adherence of $38 \%$ (Chen et al., 2012) was achieved with HT-29 MTX cells. Other examples in literature with chitosan-coated liposomes, where a $45 \%$ of adhesion was achieved was in an in vivo study performed in rats (Takeuchi et al., 2005).

\section{Conclusions}

The main conclusions of this work are the APACM's stability evidenced on the protection of the LLC bacteria. In vitro experiments demonstrated the capacity of APACM to protect and host LLC in different media simulating the human gastrointestinal conditions. Even with the LLC's capacity to produce folate, the amounts produced were insufficient to study the APACM's exchange of nutrients capacity. However, the utilization of L. plantarum UM7 allowed demonstrating that the APACM has the capacity to be permeable to the entrance of nutrients and to the release of bacterial products. These results proved that APACM has the capacity to host probiotics, allow their activity and continuous production of lactic acid. Finally, adhesion characteristics of the

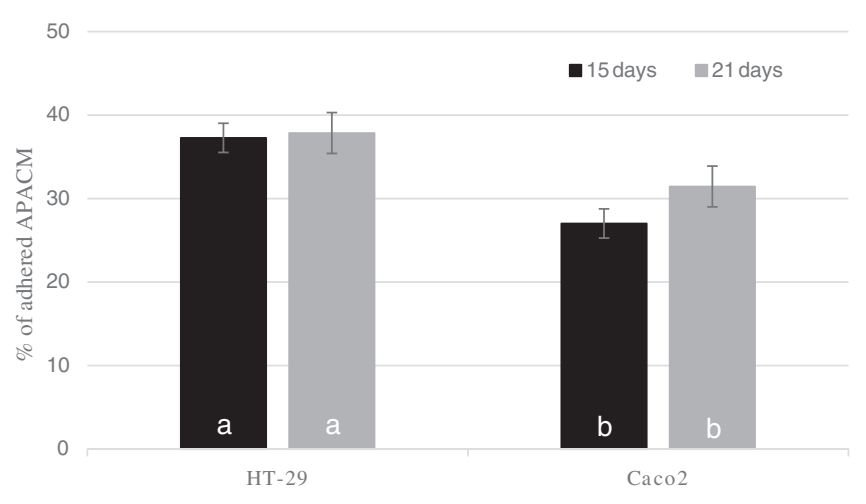

Fig. 6. Adhesion tests of APACM to HT-29 and Caco-2 cells, on cells with 15 and 21 days of differentiation. 

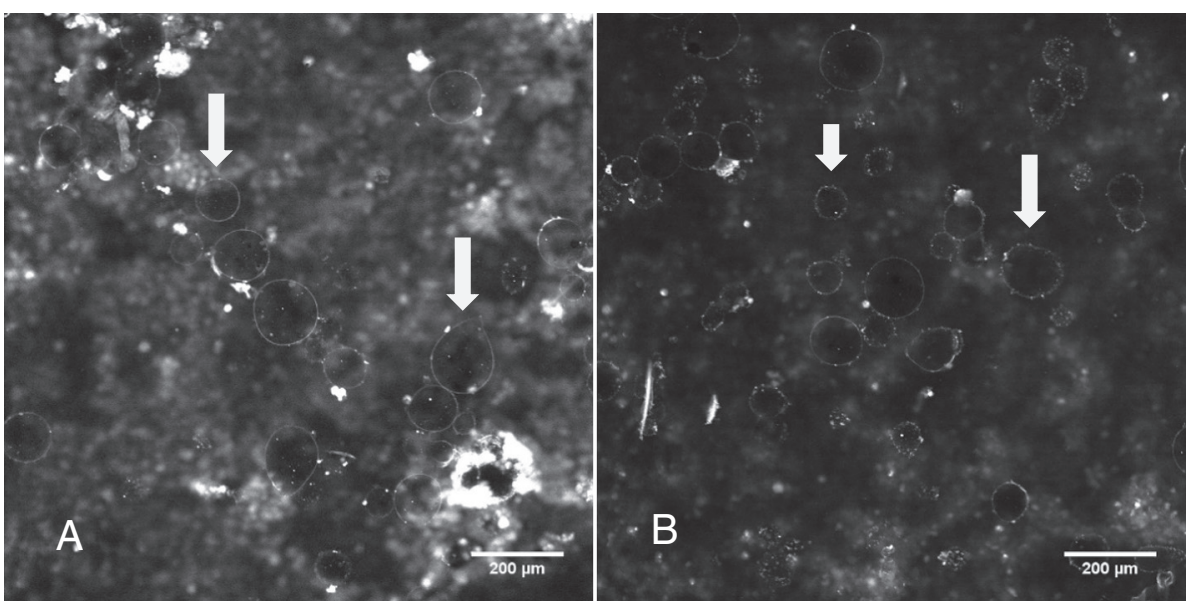

Fig. 7. APACM on Caco-2 and HT-29 cells (A and B, respectively), confocal images ( $10 \times$ lens magnification). The white arrows indicate some examples of adhered APACM.

APACM to intestinal epithelium cells were also shown, thus indicating its potential to increase the residence time in an intestinal environment. These results demonstrated the main APACM design characteristics that indicate that it might be an option to attain a continuous production of essential nutrients in situ (i.e., in the intestine), in order to increase their bioavailability.

\section{Acknowledgements}

The authors Philippe E. Ramos and Ana Pinheiro, are recipient of fellowships from the Fundacão para a Ciência e Tecnologia, POPHQREN and FSE (FCT, Portugal) through grants, SFRH/BD/80800/ 2012 and SFRH/BPD/101181/2014, respectively. The authors thank the FCT Strategic Project PEst-OE/EQB/LA0023/2013 and the project "Biolnd-Biotechnology and Bioengineering for Improved Industrial and Agro-Food Processes", ref. NORTE-07-0124-FEDER-000028 cofunded by the Programa Operacional Regional do Norte (ON.2-O Novo Norte), QREN, FEDER. The authors would like to acknowledge to Richard Francis from Lowy Cancer Research Centre (University of New South Wales) and Ana Nicolau from Centre of Biological Engineering (University of Minho) both for assistance on confocal analysis.

\section{References}

Annan, N. T., Borza, A. D., \& Hansen, L. T. (2008). Encapsulation in alginate-coated gelatin microspheres improves survival of the probiotic Bifidobacterium adolescentis 15703T during exposure to simulated gastro-intestinal conditions. Food Research International, 41(2), 184-193. http://dx.doi.org/10.1016/j.foodres.2007.11.001.

Bailey, S. W., \& Ayling, J. E. (2009). The extremely slow and variable activity of dihydrofolate reductase in human liver and its implications for high folic acid intake. Proceedings of the National Academy of Sciences of the United States of America, 106(36), 15424-15429. http://dx.doi.org/10.1073/pnas.0902072106.

Belicová, A., Mikulášová, M., \& Dušinský, R. (2013). Probiotic potential and safety properties of lactobacillus plantarum from Slovak Bryndza cheese. BioMed Research International, 2013, 8. http://dx.doi.org/10.1155/2013/760298 (ID 760298).

Brun-Graeppi, A. K. A. S., Richard, C., Bessodes, M., Scherman, D., \& Merten, O. -W. (2011) Cell microcarriers and microcapsules of stimuli-responsive polymers. Journal of Controlled Release: Official Journal of the Controlled Release Society, 149(3), 209-224. http://dx.doi.org/10.1016/j.jconrel.2010.09.023.

Callone, E., Campostrini, R., Carturan, G., Cavazza, A., \& Guzzon, R. (2008). Immobilization of yeast and bacteria cells in alginate microbeads coated with silica membranes: Procedures, physico-chemical features and bioactivity. Journal of Materials Chemistry, 18(40), 4839-4848. http://dx.doi.org/10.1039/b807301e.

Chandramouli, V., Kailasapathy, K., Peiris, P., \& Jones, M. (2004). An improved method of microencapsulation and its evaluation to protect Lactobacillus spp. in simulated gastric conditions. Journal of Microbiological Methods, 56(1), 27-35. http://dx.doi.org 10.1016/j.mimet.2003.09.002.

Chang, J. -J., Lee, Y. -H., Wu, M. -H., Yang, M. -C., \& Chien, C. -T. (2012). Preparation of electrospun alginate fibers with chitosan sheath. Carbohydrate Polymers, 87(3), 2357-2361. http://dx.doi.org/10.1016/j.carbpol.2011.10.054.

Chen, S., Cao, Y., Ferguson, L. R., Shu, Q., \& Garg, S. (2012). Evaluation of mucoadhesive coatings of chitosan and thiolated chitosan for the colonic delivery of microencapsulated probiotic bacteria. Journal of Microencapsulation, 30(May 2012), 1-13. http://dx. doi.org/10.3109/02652048.2012.700959.
Cook, M. T., Tzortzis, G., Charalampopoulos, D., \& Khutoryanskiy, V. V. (2011). Production and evaluation of dry alginate-chitosan microcapsules as an enteric delivery vehicle for probiotic bacteria. Biomacromolecules, 12(7), 2834-2840. http://dx.doi.org/10. 1021/bm200576h.

Crittenden, R. G., Martinez, N. R., \& Playne, M. J. (2003). Synthesis and utilisation of folate by yoghurt starter cultures and probiotic bacteria. International Journal of Food Microbiology, 80(3), 217-222 (Retrieved from http://www.ncbi.nlm.nih.gov/ pubmed/12423923)

Cui, J. H., Goh, J. S., Kim, P. H., Choi, S. H., \& Lee, B. J. (2000). Survival and stability of bifidobacteria loaded in alginate poly-L-lysine microparticles. International Journal of Pharmaceutics, 210(1-2), 51-59 (Retrieved from http://www.ncbi.nlm.nih.gov/ pubmed/11163987).

de Meer, K., Smulders, Y. M., Dainty, J. R., Smith, D. E. C., Kok, R. M., Stehouwer, C. D. A., ... Jakobs, C. (2005). [6S]5-methyltetrahydrofolate or folic acid supplementation and absorption and initial elimination of folate in young and middle-aged adults. European Journal of Clinical Nutrition, 59(12), 1409-1416. http://dx.doi.org/10.1038/sj.ejcn. 1602254.

De Prisco, A., Maresca, D., Ongeng, D., \& Mauriello, G. (2015). Microencapsulation by vibrating technology of the probiotic strain Lactobacillus reuteri DSM 17938 to enhance its survival in foods and in gastrointestinal environment. LWT - Food Science and Technology, 61(2), 452-462. http://dx.doi.org/10.1016/j.lwt.2014.12.011.

Dhawan, S., Singla, A. K., \& Sinha, V. R. (2004). Evaluation of mucoadhesive properties of chitosan microspheres prepared by different methods. AAPS PharmSciTech, 5(4), e67. http://dx.doi.org/10.1208/pt050467.

Emiliano, J., Juarez, M., Savoy, G., Giori, D., Guy, J., \& Leblanc, J. (2014). Microbiology applicability of a Lactobacillus amylovorus strain as co-culture for natural folate bio-enrichment of fermented milk. International Journal of Food Microbiology, 191, 10-16.

European Food Safety Authority (2014). Scientific opinion on dietary reference values for folate. EFSA Journal, 12(11), 1-59. http://dx.doi.org/10.2903/j.efsa.2014.3893.

Food and Agriculture Organization of the United Nations/World Health Organization (2001r). Health and nutritional properties of probiotics in food including powder milk with live lactic acid bacteria. Food and Agriculture Organization of the United Nations World, 1-34 (October).

García-Ceja, A., Mani-López, E., Palou, E., \& López-Malo, A. (2015). Viability during refrigerated storage in selected food products and during simulated gastrointestinal conditions of individual and combined lactobacilli encapsulated in alginate or alginatechitosan. LWT - Food Science and Technology, 63(1), 482-489. http://dx.doi.org/10. 1016/j.lwt.2015.03.071.

Garcia-Fuentes, M., Prego, C., Torres, D., \& Alonso, M. J. (2005). A comparative study of the potential of solid triglyceride nanostructures coated with chitosan or poly(ethylene glycol) as carriers for oral calcitonin delivery. European Journal of Pharmaceutical Sciences: Official Journal of the European Federation for Pharmaceutical Sciences, 25(1), 133-143. http://dx.doi.org/10.1016/j.ejps.2005.02.008.

Gardiner, G. E., Casey, P. G., Casey, G., Brendan, P., Lawlor, P. G., Hill, C., ... Lynch, P. B. (2004). Relative ability of orally administered Lactobacillus murinus to predominate and persist in the porcine gastrointestinal tract. Applied and Environmental Microbiology, 70, 1895-1906. http://dx.doi.org/10.1128/AEM.70.4.1895.

Gbassi, G. K., Vandamme, T., Ennahar, S., \& Marchioni, E. (2009). Microencapsulation of Lactobacillus plantarum spp in an alginate matrix coated with whey proteins. International Journal of Food Microbiology, 129(1), 103-105. http://dx.doi.org/10. 1016/j.ijfoodmicro.2008.11.012.

Genisheva, Z., Teixeira, J. a., \& Oliveira, J. M. (2014). Immobilized cell systems for batch and continuous winemaking. Trends in Food Science and Technology, 40(1), 33-47. http://dx.doi.org/10.1016/j.tifs.2014.07.009.

George, M., \& Abraham, T. E. (2006). Polyionic hydrocolloids for the intestinal delivery of protein drugs: Alginate and chitosan - A review. Journal of Controlled Release: Official Journal of the Controlled Release Society, 114(1), 1-14. http://dx.doi.org/10.1016/j. jconrel.2006.04.017.

Ghersd, O., Jolliffe, I. G., Hampson, F. C., \& Dettmar, P. W. (1998). The enhancement of the bioadhesive properties of calcium alginate gel beads by coating with chitosan. Journal of Pharmaceutics, 175, 237-246. 
Gombotz, W., \& Wee, S. (1998). Protein release from alginate matrices. Advanced Drug Delivery Reviews, 31(3), 267-285 (Retrieved from http://www.ncbi.nlm.nih.gov/ pubmed/10837629).

Graff, S., Hussain, S., Chaumeil, J. C., \& Charrueau, C. (2008). Increased intestinal delivery of viable Saccharomyces boulardii by encapsulation in microspheres. Pharmaceutical Research, 25(6), 1290-1296. http://dx.doi.org/10.1007/s11095-007-9528-5.

Gueimonde, M., \& Salminen, S. (2006). New methods for selecting and evaluating probiotics. Digestive and Liver Disease, 38(2), 242-247. http://dx.doi.org/10.1016/ S1590-8658(07)60003-6.

Holasová, M., Fiedlerová, V., Roubal, P., \& Pechacová, M. (2002). Biosynthesis of folates by lactic acid bacteria and propionibacteria in fermented milk. Czech Journal of Food Science, 22(5), 175-181.

Huet, G., Kim, I., de Bolos, C., Lo-Guidice, J. M., Moreau, O., Hemon, B., ... Degand, P. (1995). Characterization of mucins and proteoglycans synthesized by a mucin-secreting HT29 cell subpopulation. Journal of Cell Science, 108(3), 1275-1285 (Retrieved from http://jcs.biologists.org/content/108/3/1275.short|nhttp://www.ncbi.nlm.nih.gov/ pubmed/7622610).

Hugenschmidt, S., Schwenninger, S. M., Gnehm, N., \& Lacroix, C. (2010). Screening of a natural biodiversity of lactic and propionic acid bacteria for folate and vitamin B12 production in supplemented whey permeate. International Dairy Journal, 20(12), 852-857. http://dx.doi.org/10.1016/j.idairyj.2010.05.005.

Hugenschmidt, S., Schwenninger, S. M., \& Lacroix, C. (2011). Concurrent high production of natural folate and vitamin B12 using a co-culture process with Lactobacillus plantarum SM39 and Propionibacterium freudenreichii DF13. Process Biochemistry, 46(5), 1063-1070. http://dx.doi.org/10.1016/j.procbio.2011.01.021.

International Food Policy Reasearch Institute, I (2015). Global nutrition report. http://dx.doi. org/10.2499/9780896298835.

Iyer, C., \& Kailasapathy, K. (2005). Effect of co-encapsulation of probiotics with prebiotics on increasing the viability of encapsulated bacteria under in vitro acidic and bile salt conditions and in yogurt. Journal of Food Science, 70(1), M18-M23. http://dx.doi.org/ 10.1111/j.1365-2621.2005.tb09041.x.

Iyer, C., Phillips, M., \& Kailasapathy, K. (2005). Release studies of Lactobacillus casei strain Shirota from chitosan-coated alginate-starch microcapsules in ex vivo porcine gastrointestinal contents. Letters in Applied Microbiology, 41(6), 493-497. http://dx.doi.org/ 10.1111/j.1472-765X.2005.01778.x.

Jacob, R. A. (2000). Folate, DNA methylation, and gene expression: Factors of nature and nurture. The American Journal of Clinical Nutrition, 72, 903-904.

Jeong, D. -W., Choi, Y. C., Lee, J. M., Kim, J. H., Lee, J. -H., Kim, K. H., \& Lee, H. J. (2006). Isolation and characterization of promoters from Lactococcus lactis ssp. cremoris LM0230. Food Microbiology, 23(1), 82-89. http://dx.doi.org/10.1016/j.fm.2005.01.006.

Kamalian, N., Mirhosseini, H., Mustafa, S., \& Manap, M. Y. A. (2014). Effect of alginate and chitosan on viability and release behavior of Bifidobacterium pseudocatenulatum G4 in simulated gastrointestinal fluid. Carbohydrate Polymers, 111, 700-706. http://dx.doi. org/10.1016/j.carbpol.2014.05.014.

Khutoryanskiy, V. V. (2011). Advances in mucoadhesion and mucoadhesive polymers. Macromolecular Bioscience, 11(6), 748-764. http://dx.doi.org/10.1002/ mabi.201000388.

Kilstrup, M., \& Hammer, K. (2000). Short communication: Salt extends the upper temperature limit for growth of Lactococcus lactis ssp. cremoris on solid M17 medium. Journal of Dairy Science, 83(7), 1448-1450. http://dx.doi.org/10.3168/jds. S0022-0302(00)75015-6.

Kleinberger, R. M., Burke, N. A. D., Dalnoki-Veress, K., \& Stöver, H. D. H. (2013). Systematic study of alginate-based microcapsules by micropipette aspiration and confocal fluorescence microscopy. Materials Science \& Engineering, C: Materials for Biological Applications, 33(7), 4295-4304. http://dx.doi.org/10.1016/j.msec.2013.06.033.

Klingberg, T. D., \& Budde, B. B. (2006). The survival and persistence in the human gastrointestinal tract of five potential probiotic lactobacilli consumed as freeze-dried cultures or as probiotic sausage. International Journal of Food Microbiology, 109(1-2), 157-159. http://dx.doi.org/10.1016/j.ijfoodmicro.2006.01.014.

Krasaekoopt, W., Bhandari, B., \& Deeth, H. (2004). The influence of coating materials on some properties of alginate beads and survivability of microencapsulated probiotic bacteria. International Dairy Journal, 14(8), 737-743. http://dx.doi.org/10.1016/j. idairyj.2004.01.004.

Krasaekoopt, W., Bhandari, B., \& Deeth, H. C. (2006). Survival of probiotics encapsulated in chitosan-coated alginate beads in yoghurt from UHT- and conventionally treated milk during storage. LWT - Food Science and Technology, 39(2), 177-183. http://dx. doi.org/10.1016/j.lwt.2004.12.006.

Laiño, J. E., Leblanc, J. G., \& Savoy de Giori, G. (2012). Production of natural folates by lactic acid bacteria starter cultures isolated from artisanal Argentinean yogurts. Canadian Journal of Microbiology, 58(5), 581-588. http://dx.doi.org/10.1139/w2012-026.

LeBlanc, J. G., Milani, C., de Giori, G. S., Sesma, F., van Sinderen, D., \& Ventura, M. (2013). Bacteria as vitamin suppliers to their host: A gut microbiota perspective. Current Opinion in Biotechnology, 24(2), 160-168. http://dx.doi.org/10.1016/j.copbio.2012. 08.005.

Lee, J. S., Cha, D. S., \& Park, H. J. (2004). Survival of freeze-dried Lactobacillus bulgaricus KFRI 673 in chitosan-coated calcium alginate microparticles. Journal of Agricultural and Food Chemistry, 52, 7300-7305. http://dx.doi.org/10.1021/jf040235k.

Lin, M. Y., \& Young, C. M. (2000). Folate levels in cultures of lactic acid bacteria. International Dairy Journal, 10, 409-413.

Luo, Y., \& Wang, Q. (2014). Recent development of chitosan-based polyelectrolyte complexes with natural polysaccharides for drug delivery. International Journal of Biological Macromolecules, 64, 353-367. http://dx.doi.org/10.1016/j.ijbiomac.2013. 12.017.

Ma, Y., Fuchs, A. V., Boase, N. R. B., Rolfe, B. E., Coombes, A. G. A., \& Thurecht, K. J. (2015). The in vivo fate of nanoparticles and nanoparticle-loaded microcapsules after oral administration in mice: Evaluation of their potential for colon-specific delivery.
European Journal of Pharmaceutics and Biopharmaceutics, 94, 393-403. http://dx.doi. org/10.1016/j.ejpb.2015.06.014.

Matsumura, K., Nakajima, N., Sugai, H., \& Hyon, S. H. (2014). Self-degradation of tissue adhesive based on oxidized dextran and poly-L-lysine. Carbohydrate Polymers, 113, 32-38. http://dx.doi.org/10.1016/j.carbpol.2014.06.073.

Mi, Y., Su, R., Fan, D. D., Zhu, X. L., \& Zhang, W. N. (2013). Preparation of N,Ocarboxymethyl chitosan coated alginate microcapsules and their application to Bifidobacterium longum BIOMA 5920. Materials Science and Engineering C, 33 , 3047-3053. http://dx.doi.org/10.1016/j.msec.2013.03.035.

Minekus, M., Alminger, M., Alvito, P., Ballance, S., Bohn, T., Bourlieu, C., ... Brodkorb, A. (2014). A standardised static in vitro digestion method suitable for food - An international consensus. Food \& Function, 5(6), 1113-1124. http://dx.doi.org/10.1039/ c3fo60702j.

Mokarram, R. R., Mortazavi, S. a., Najafi, M. B. H., \& Shahidi, F. (2009). The influence of multi stage alginate coating on survivability of potential probiotic bacteria in simulated gastric and intestinal juice. Food Research International, 42(8), 1040-1045. http:/ dx.doi.org/10.1016/j.foodres.2009.04.023.

Morris, M. C., \& Tangney, C. C. (2007). Is dietary intake of folate too low? Lancet, 369, $166-167$.

Motta, C. (2015). PhD thesis. Pseudocereais como Ingredientes de Formulações Destinadas a uma Alimentação Especial. Faculdade de Ciências da Nutrição e Alimentação da Universidade do Porto.

Patel, P. J., Singh, S. K., Panaich, S., \& Cardozo, L. (2014). The aging gut and the role of prebiotics, probiotics, and synbiotics: A review. Journal of Clinical Gerontology and Geriatrics, 5(1), 3-6. http://dx.doi.org/10.1016/j.jcgg.2013.08.003.

Ramos, C. L., Thorsen, L., Schwan, R. F., \& Jespersen, L. (2013). Strain-specific probiotics properties of Lactobacillus fermentum, Lactobacillus plantarum and Lactobacillus brevis isolates from Brazilian food products. Food Microbiology, 36(1), 22-29. http://dx.doi. org/10.1016/j.fm.2013.03.010.

Ramos, P. E., Cerqueira, M. A., Abrunhosa, L., Cook, M., Charalampopoulos, D. Khutoryanskiy, V. V., ... Vicente, A. A. (2015). Probiotic microcarrier: a continuous folate producer. IFT 2015 Annual Meeting and Food Expo (pp. 115) (Retrieved from http://repositorium.sdum.uminho.pt/handle/1822/36803).

Ramos, P. E., Cerqueira, M. A., Vicente, A. A., \& Teixeira, J. A. (2016). Cápsula imobilizadora de probióticos para a produção de micronutrientes no intestino. (Portugal).

Rattanaprasert, M., Roos, S., Hutkins, R. W., \& Walter, J. (2014). Quantitative evaluation of synbiotic strategies to improve persistence and metabolic activity of Lactobacillus reuteri DSM 17938 in the human gastrointestinal tract. Journal of Functional Foods, 10, 85-94. http://dx.doi.org/10.1016/j.jff.2014.05.017.

Sarmento, B., Ribeiro, A., Veiga, F., Sampaio, P., Neufeld, R., \& Ferreira, D. (2007). Alginate chitosan nanoparticles are effective for oral insulin delivery. Pharmaceutical Research, 24(12), 2198-2206. http://dx.doi.org/10.1007/s11095-007-9367-4.

Scott, J. M. (1999). Folate and vitamin B12. The Proceedings of the Nutrition Society, 58(2), 441-448. http://dx.doi.org/10.1017/S0007114508958001.

Sheu, T. Y., \& Marshall, R. T. (1993). Microentrapment of lactobacilli in calcium alginate gels. Journal of Food Science, 54(3), 557-561.

Sinha, V. R., Singla, A. K., Wadhawan, S., Kaushik, R., Kumria, R., Bansal, K., \& Dhawan, S. (2004). Chitosan microspheres as a potential carrier for drugs. International Journa of Pharmaceutics, 274(1-2), 1-33. http://dx.doi.org/10.1016/j.ijpharm.2003.12.026.

Sohail, A., Turner, M. S., Coombes, A., Bostrom, T., \& Bhandari, B. (2011). Survivability of probiotics encapsulated in alginate gel microbeads using a novel impinging aerosols method. International Journal of Food Microbiology, 145(1), 162-168. http://dx.doi. org/10.1016/j.ijfoodmicro.2010.12.007.

Sybesma, W., Starrenburg, M., Tijsseling, L., Hoefnagel, M. H. N., \& Hugenholtz, J. (2003). Effects of cultivation conditions on folate production by lactic acid bacteria. Applied and Environmental Microbiology, 69(8), 4542-4548. http://dx.doi.org/10.1128/AEM 69.8.4542.

Takeuchi, H., Thongborisute, J., Matsui, Y., Sugihara, H., Yamamoto, H., \& Kawashima, Y. (2005). Novel mucoadhesion tests for polymers and polymer-coated particles to design optimal mucoadhesive drug delivery systems. Advanced Drug Delivery Reviews, 57(11), 1583-1594. http://dx.doi.org/10.1016/j.addr.2005.07.008.

Tam, S. K., Bilodeau, S., Dusseault, J., Langlois, G., Hallé, J. -P., \& Yahia, L. H. (2011). Biocompatibility and physicochemical characteristics of alginate-polycation microcapsules Acta Biomaterialia, 7(4), 1683-1692. http://dx.doi.org/10.1016/j.actbio.2010.12.006.

Tiihonen, K., Ouwehand, A. C., \& Rautonen, N. (2010). Human intestinal microbiota and healthy ageing. Ageing Research Reviews, 9(2), 107-116. http://dx.doi.org/10.1016/j. arr.2009.10.004

Uludag, H., De Vos, P., \& Tresco, P. A. (2000). Technology of mammalian cell encapsulation. Advanced Drug Delivery Reviews, 42(1-2), 29-64 (Retrieved from http://www ncbi.nlm.nih.gov/pubmed/10942814).

Wolf, B. W., Garleb, K. a., Ataya, D. G., \& Casas, I. a. (1995). Safety and tolerance of Lactobacillus reuteri in healthy adult male subjects. Microbial Ecology in Health and Disease, 8(2), 41-50. http://dx.doi.org/10.3109/08910609509141381.

World Health Organization (2012). Global nutrition targets 2025 low birth weight policy brief. 5. (pp. 1-8). Department of Nutrition for Health and Development, 1-8 (WHO/NMH/NHD/14.5)

World Health Organization (2014a). Global nutrition targets 2025 stunting policy brief. 9 (pp. 1-12). Department of Nutrition for Health and Development, 1-12 (WHO/ $\mathrm{NMH} / \mathrm{NHD} / 14.3$ ).

World Health Organization (2014b). Global nutrition targets 2025 anaemia policy brief. 6 . (pp. 1-7). Department of Nutrition for Health and Development, 1-7 (WHO/NMH/ $\mathrm{NHD} / 14.4)$.

Zhang, X., Xie, Y., Koh, C. G., \& James Lee, L. (2009). A novel 3-D model for cell culture and tissue engineering. Biomedical Microdevices, 11(4), 795-799. http://dx.doi.org/10. 1007/s10544-009-9294-8. 